\title{
Maintenance of Underground Granaries in Medieval Towns; Case Study from Padowetz, Brno, Czech Republic
}

\author{
Lenka Lisáa $^{*}$, Marek Peška ${ }^{\mathrm{b}}$, David Merta ${ }^{\mathrm{b}}$, Miloš Gregor $^{\mathrm{c}}$ \\ IInstitute of Geology CAS, Rozvojová 269, Prague 6, 165 00, Czech Republic \\ ${ }^{b}$ Archaia Brno, Bezručova 15/78, Brno, 602 00, Czech Republic \\ 'Independent researcher, Rovníková 8, 82102 Bratislava, Slovakia
}

\section{ARTICLE INFO}

\section{Article history:}

Received: $28^{\text {th }}$ August 2017

Accepted: $6^{\text {th }}$ November 2017

DOI: http://dx.doi.org/ 10.24916/iansa.2017.2.5

Key words:

corny holes

storage pits

geoarchaeology

micromorphology

phytoliths

\section{Introduction}

Underground granaries are silos dug in the ground to store cereals. These underground constructions constitute the traditional way of cereal storage in all Slavic countries up to the $18^{\text {th }}$ century (Kunz 2004). They are mainly typical for Early Medieval and Medieval rural environments (Donat 1980, 80-83; Dostál 1985, 40-43; Klanica 2008, 183-186; Kuna, Profantová et al. 2005, 117-118; Kudrnáč 1958; Nekuda, 2007, 49-51; Pleinerová 2000, 213) as well as in prehistory (Gašpar, in press). Rarely were underground granaries also built in towns. We detect them, for example, in Brno up to the $12^{\text {th }}$, maximally $14^{\text {th }}$ century (Procházka 2012; 2013).

The technology of granaries is nearly unknown in the Czech Republic. By contrast, in Slovakian lowlands around the river Donau and Tisa granaries were used up to the end of the Second World War (Kunz 2004). Some notes about the

*Corresponding author. E-mail: lisa@gli.cas.cz use of granaries in the Hungarian agricultural literature of $18^{\text {th }}$ and $19^{\text {th }}$ century may also be found (Kunz 2004). These storage pits usually do not occur in sandy soils and forested areas. The best conditions for the construction of granaries are the dry plains of north and south Mediterranean areas, in the plains around the Danube and the north coastal areas of the Black Sea, in the Middle East, in central Asia, or in southern Siberia. With good soil conditions, where there is minimal erosion, they have been preserved till the present day used by shepherds in steppe regions. The main factors in the spread in use of granaries are dry soil and little rain. That is why there is a difference between the northern limit for growing cereals and the northern limit in the historical occurrence of granaries. The southern limits show a similar picture. The prehistorical phase of granaries in central Europe shows a unity in their construction. The granaries were built the same way until people were converted to the modern way of agriculture (Kunz 2004).

Up to now we have detected only a few such findings dated to the period of the $13^{\text {th }}$ to $14^{\text {th }}$ centuries in the centre of Brno 


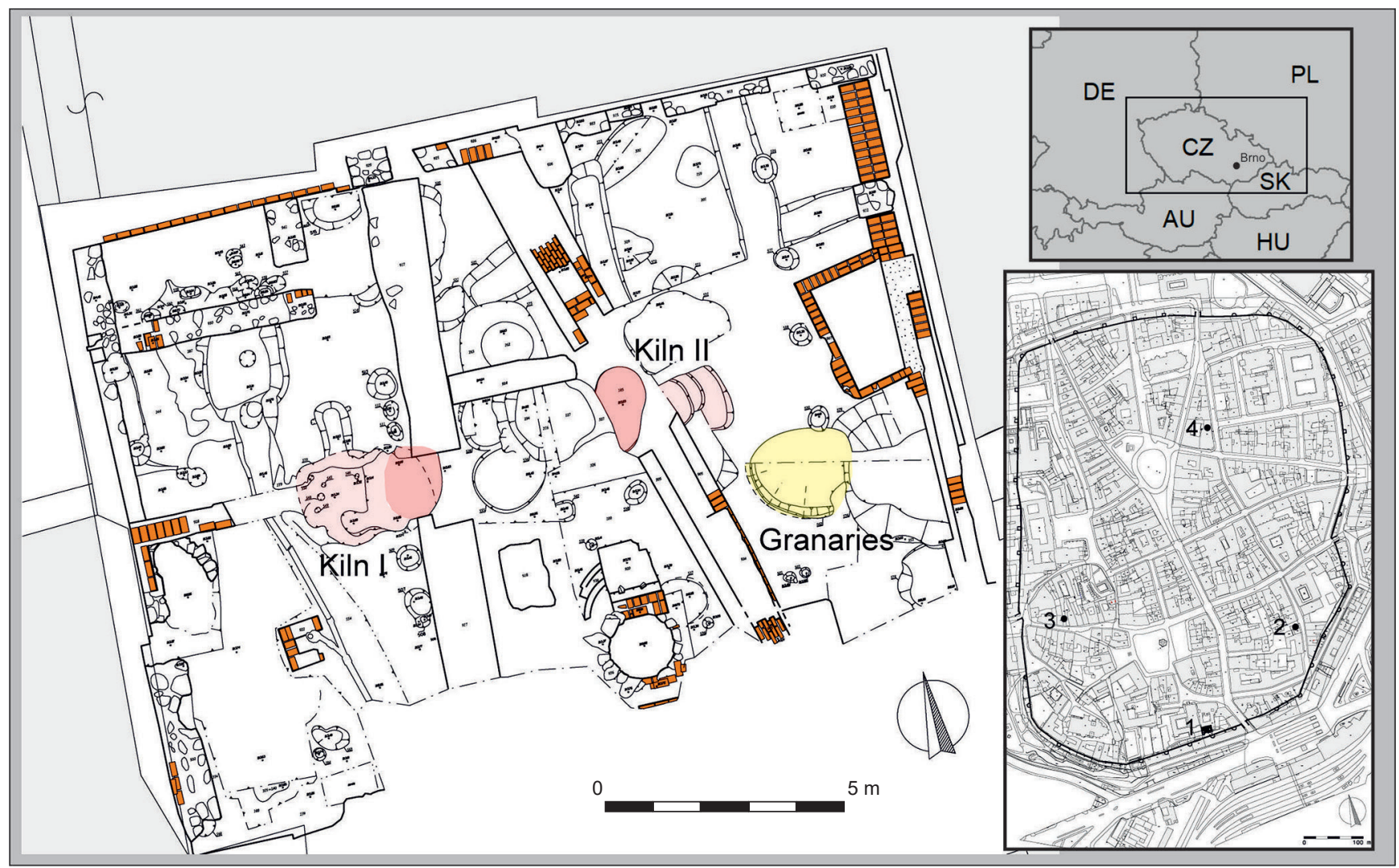

Figure 1. Location of the study area together with the plan of the excavations and a section of the underground granary. 1) Bašty street No. 2; 2) Josefská street No. 8; 3) Starobrněnská street No. 18; 4) Kobližná street No. 3.

(Procházka 2012, 1012; 2013). Generally the underground granaries are often pear-shaped, with small openings and diameters of up to three metres at their widest point (Kunz 2004). The underground granaries excavated up till now in the Brno town area are usually pear-shaped with diameters of $1.8 \mathrm{~m}$ (2.2 m respectively) reaching a depth of 3.6 metres. These have been detected mainly in the distal parts of burgher plots (Kobližná 3, Josefská 8, Starobrněnská 18; Procházka 2013, 110; 2012, 203; 2000, 58). Due to the fact that most of the plots demarcated in the second quarter of the $13^{\text {th }}$ century do not show any underground granary locations, we can connect their appearance mainly with the older rural tradition of the local inhabitants. While the need for cereals in the towns lasted, unlike in the villages there was no need to store added cereals for sowing. Additionally there was the need to store not only cereals, but also craft and other raw materials. The urban character of the sunken features at that time was usually already connected with the construction of earthen house cellars (Holub et al. 2005). The storage of the ceramic vessels (Nekuda, Reichertová 1968, 63; Procházka, Peška 2007, 168) used to store cereals had in fact replaced the need for underground granaries.

To preserve the grain in an anaerobic environment, the pits were filled to the top and then hermetically sealed. The oxygen remaining in the silo would alter (decompose) the grain in contact with the earthen walls, but would be quickly used up as it turned to carbon dioxide. Cereals could thus be kept for several years without fermenting and without being attacked by insects. Among all these silos, certain cylindrical pits may be distinguished by their greater depth and by the existence of internal compartments associated with a raised floor. This arrangement solved the problem of excess humidity by creating an opening for coals or heated stones to be introduced, thus drying out the silo's contents. We know that a part of the stored grain was thus steamed or grilled. These pits, which were normally grouped together a short distance from dwellings, were no doubt used to store excess grain from the harvest. After a period of use - which we believe to be relatively short - these silos were often converted into waste pits (Kunz 2004).

There is a little known about the maintenance of underground granaries from the $12^{\text {th }}-14^{\text {th }}$ century, especially in the town environment of the city of Brno. The main aim of this paper is therefore an evaluation of the possible maintenance methods of the underground granary excavated at the edge of the Brno medieval burger plot, and the information value of such sedimentary records for understanding the medieval practices of these storage pits.

\section{Material and methods}

The construction of an underground parking area for the Padowetz Hotel in 2008 (Bašty Street No. 2), was the 
reason for the rescue excavations led by the archaeological company Archaia Brno. The study area, at an altitude of $214 \mathrm{~m}$ a.s.1., was located in the internal part of plot 351, Bašty Street, on the gentle lower slopes of the Petrov Hill. This area belongs historically to the medieval quarter of Brno town (Quartale Brunensis), in the close neighbourhood of the city walls and Jewish gateway (Porta Judeorum). The excavated area had the dimensions of $18 \times 13 \mathrm{~m}$. The geological background was composed of loess with a partly- preserved soil cover $(20-30 \mathrm{~cm})$. There were the preserved foundations of two houses, two ovens and one underground storage pit interpreted as an underground granary (Figure 1). The infill of the granary was quite homogenous with a laminated bottom part. This part was described according to field sedimentological criteria, based on parameters such as colour, texture, and internal organization. The colour of the sediments was identified in both a wet and dry state using a Munsell soil colour chart. The two micromorphological

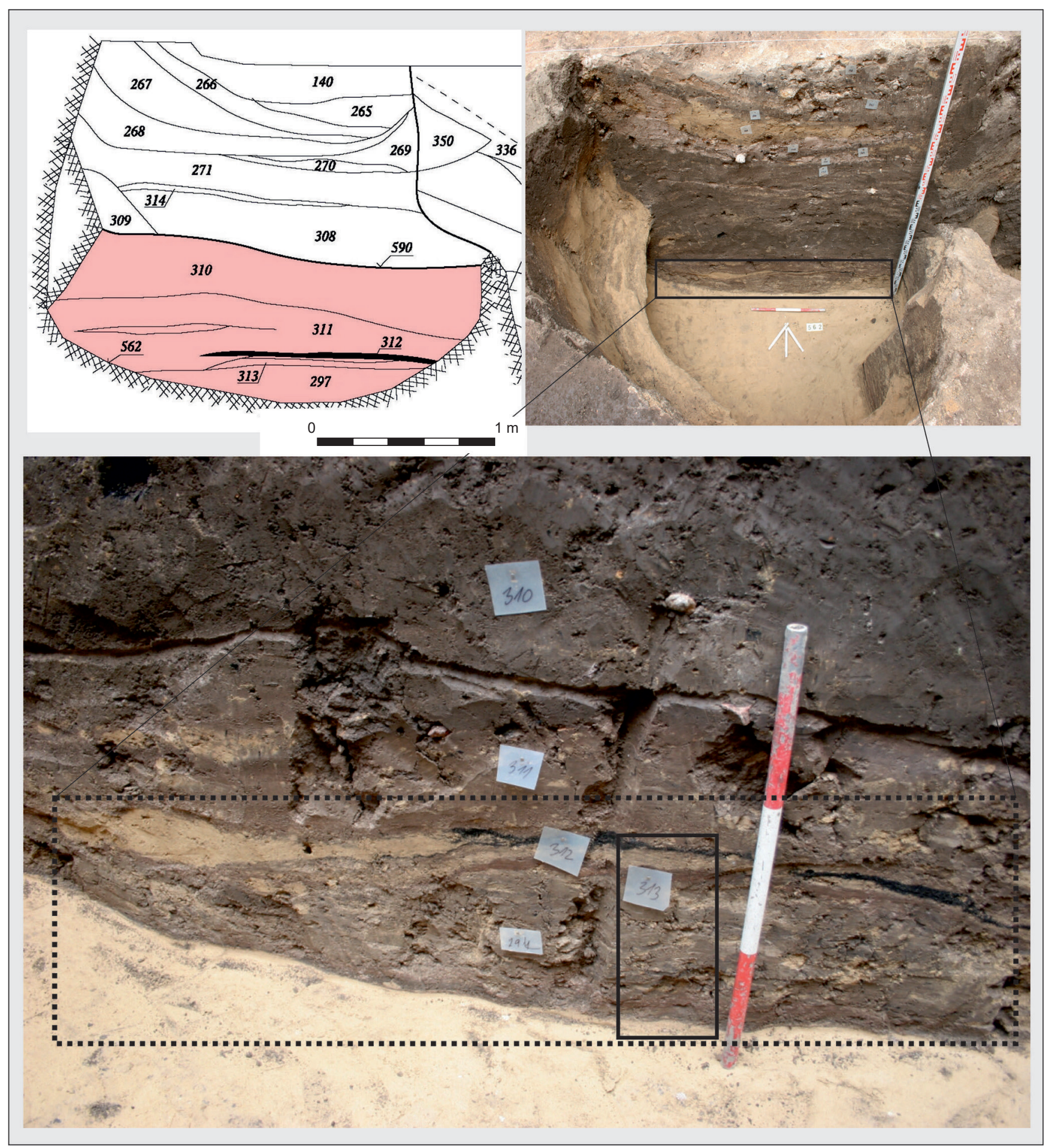

Figure 2. Documentation of the underground granary from Bašty Street together with a detail of the laminated bottom of this granary. 
samples from this layer were collected using a Kubiena box. Large thin sections (approximately $140 \times 70 \mathrm{~mm}$ ) were prepared in the laboratory of Julie Boreham, Reach, GB (www.earthslides.com) and examined under plain and cross polarised light at different magnifications (40-800×). The descriptions and interpretations mainly followed the guidelines used by Stoops (2003) and Stoops et al. (2010).

The mineralogical composition of the black uppermost part of the laminated fill of the granary was estimated with help of X-ray powder diffraction analyses using Bruker D-8 Advance (Department of Mineralogy and Petrology, Comenius University, Bratislava) operating at $440 \mathrm{kV}$ and $40 \mathrm{~mA}$ using $\mathrm{Cu}$ antikathod $(\mathrm{Cuk} \alpha 1=\AA)$ and a Ni filter. The can speed recording intensities was in $0.01^{\circ} 2 \theta$ per 1 second and oriented powder specimens were prepared.

\section{Results}

\subsection{Morphological and sedimentary description of the granary infill}

The underground granary mouth had an elliptical shape with a longer axis of 1.5 metres and shorter axis of 1 metre. The maximal diameter of the sunken part of the granary was
$2.4 \mathrm{~m}$ and the depth of the granary (measured from the former surface altitude) reached $2.2 \mathrm{~m}$. The granary had originally a "bag-like" shape, but the walls had partly collapsed and the shape of it was a little deformed. This seems to be a common effect documented in underground granaries and it is a testament to the gradual decline of the granary. The pit of the granary did not cut any older situation. Later on, the granary infill had been cut by a much younger feature (right side of photo, Figure 2) from the beginning of the $13^{\text {th }}$ and $14^{\text {th }}$ century. This feature indirectly more or less dates the terminal infill of the granary (layers 268 and 265, Figure 2).

The bottom part of the granary infill was composed of thin bands (numbers 297, 311, 312, 313). The five lithologically different layers were divided macroscopically (Figure 2). The layer 297 is a light brown, tough plastic loam containing fragments of yellow plastic loam (30\%), occasionally fragments of burned loam, and infrequently of microcharcoal. The layer 310 is dark brown, tough plastic loam with occasional microcharcoal, burned loam, small lenses of yellow plastic loam, small fragments of bones, ceramic shreds and small pebbles. The layer 311 is a brown, tough plastic loam with occasional microcharcoal and lenses of yellow plastic loam. The layer 313 is a brown, tough plastic loam. The layer 312 is composed of yellow plastic
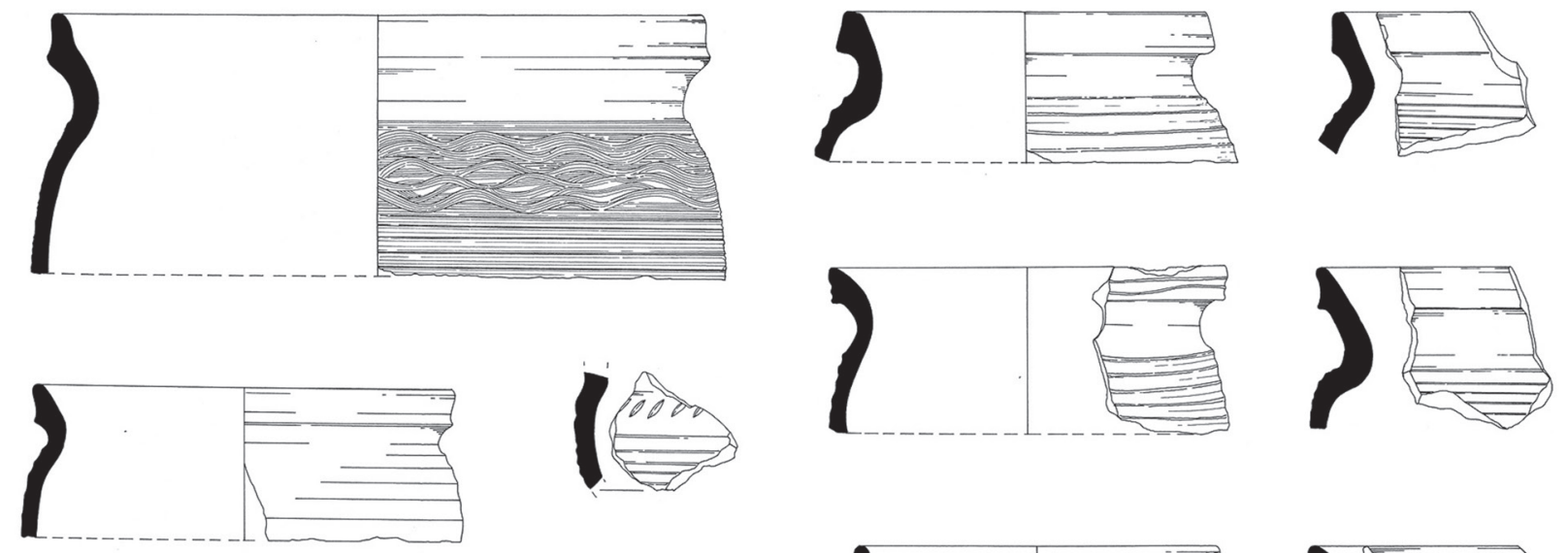

\section{,}
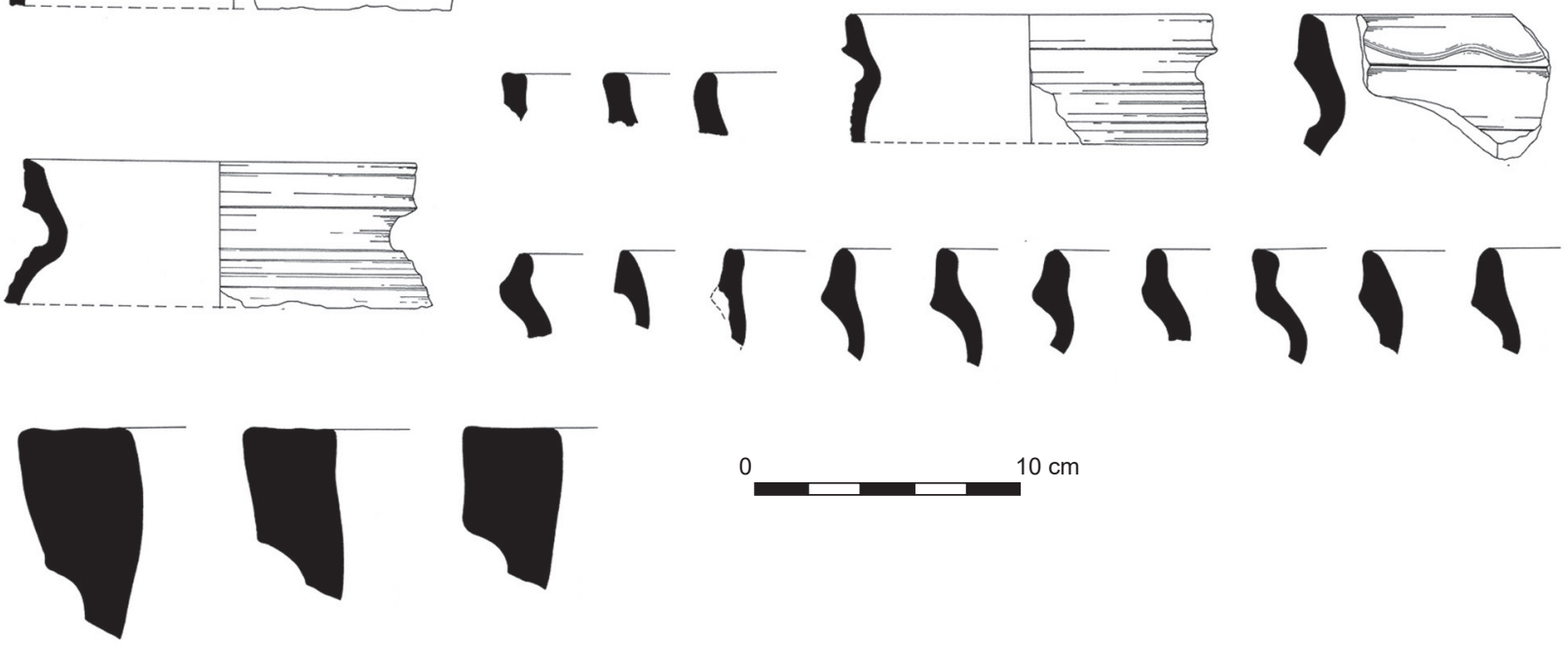

Figure 3. The main types of the pottery findings. 

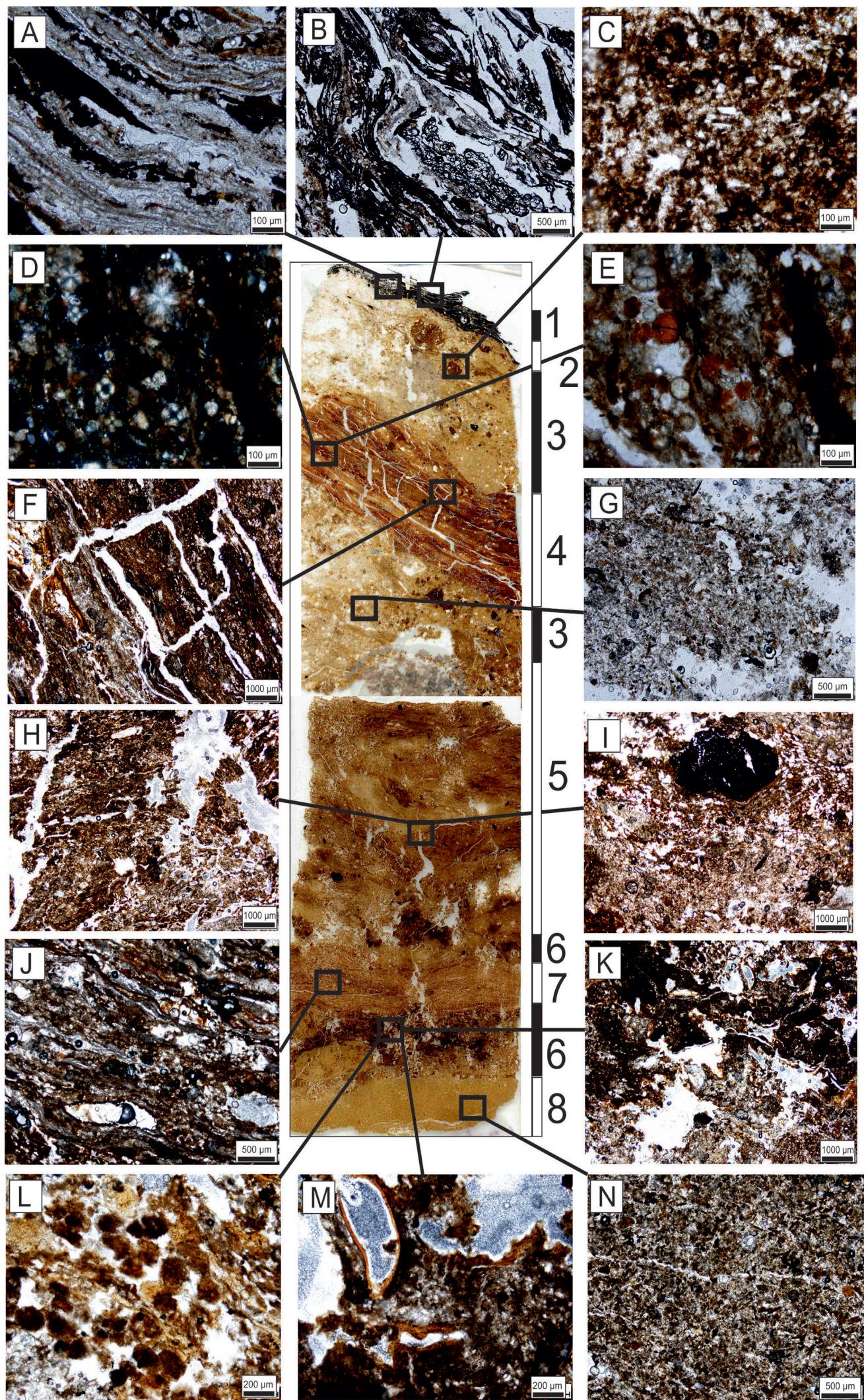

Figure 4. Micromorphological documentation of the thin sections. The dimension of one thin section is $12 \times 7 \mathrm{~cm}$. The divided micromorphological features were documented for each of the micromorphologically different layers. A, B - layer composed of burned straw with well preserved phytolith accumulations (PPL - plane polarized light); $\mathrm{C}$ - brown homogenous matrix of redeposited soil fragments (PPL); $\mathrm{D}-\mathrm{CaCO}_{3}$ and phosphatic spherulites recorded within heavily-impregnated straw (XPL - cross polarized light); E - the same photo but in PPL; F - fragmented layer of straw heavily impregnated by phosphates (PPL); G - loess material bioturbated with fragments of organic matter and microcharcoal (PPL); H, I - fragmented relicts of organic matter, mainly straw (PPL); J - bands of straw with clearly visible articulated phytoliths (PPL); K - decomposed and bioturbated organic matter (PPL); L - excremental features (PP); M - clay coating rich in phosphates (PPL); $\mathrm{N}$ - homogenous loess background (PPL). 


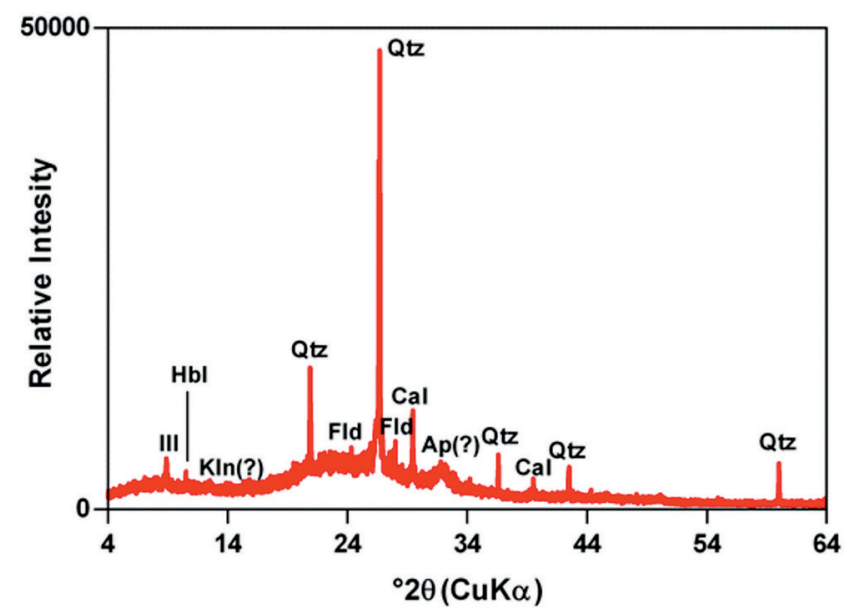

Figure 5. PXRD diffraction pattern (sample B/OJ-312). Abbrevations: Ill - illite, Kln - kaolinite, Hbl - amphibole (hornblende), Qtz - quartz, Fld - feldspars, Cal - calcite, Ap - apatite.

loam and in some parts covered by black thin layer (the fifth divided layer, see the PXRD composition below as well as micromorphological description, the unit 1). The transitions between bands are sharp and these bands, except for the dark brown layer 310, are non-continuous (Figure 2).

The set of bands is covered by redeposited soil including ceramic shards. These shards belong to the non-graphitic ceramic types of brown to grey hues. The found ceramic shards (Figure 3) show that the vessels were partly wheelthrown. Their surface is slightly rough to rough, the grain size composition is medium to coarse. Sand was used as the temper. The decoration is composed mainly of lines, occasionally by ripples and scratches. All described shards were archaeologically dated to the second half of the $12^{\text {th }}$ century and the turn to the $13^{\text {th }}$ century, i.e. into the so-called pre-urban period (the horizon RS 4.3).

\subsection{Micromorphology}

The laminated bottom of the underground granary from Padowetz displays several types of laminae differing mainly by colour (Figures 2 and 4). Some of these laminae appear repeatedly and their composition was well distinguished under the polarising microscope. According to the micromorphological descriptions, eight microphases were divided (Figure 4, Table 1). It seems that the laminated infill at the bottom of the granary is composed of redeposited organic matter and loess, which previously composed the walls of the granary and which were redeposited on the bottom of the granary due to maintenance processes.

\subsection{Mineralogical description of black layer}

The estimated composition of the analyzed sample clearly shows the presence of clay as well as non-clay minerals (Figure 5). The higher background clearly visible in the PXRD pattern corresponds to the presence of an amorphous phase, which can be related to the presence of iron oxides or hydroxides. The main phase corresponds to quartz (with typical diffraction lines at 0.426 and $0.334 \mathrm{~nm}$ ). Calcite (typical diffraction lines at 0.386 and $0.303 \mathrm{~nm}$ ) as well as various types of feldspars, including potassium feldspars, and plagioclases were detected in the mineralogical composition of the sample as well. A broad maximum in the range of $30-32{ }^{\circ} 2 \theta$ with maximum diffraction intensity at $0.281 \mathrm{~nm}$ - can most probably correspond to the presence of hydroxylapatite, but the presence of this mineral phase is questionable due to the presence of only one diffraction line and a higher background. The sample also shows the presence of a mineral from the amphibole group, but due to the presence of only one diffraction maximum, it is impossible to identify the exact type of the amphibole.

Clay minerals are represented by the presence of illite, which creates the dominant phase. Most probably the sample also contains kaolinite, but its presence is obscured by the higher background. A detailed mineralogical characterization of the sample could be achieved by analyzing the $>2 \mu \mathrm{m}$ fraction.

\section{Discussion}

\subsection{Presence of underground granary in the town environment}

Underground granaries had been already documented in the area of Moravia up to the $18^{\text {th }}$ century (Kunz 2004), but mainly in the village environment. Their appearance in towns is very rare and nearly unknown. However, a few findings were documented in the Brno town inside the medieval walls, though belonging mainly to the $12-13^{\text {th }}$ century (Procházka 2012, 1012; 2013). The excavated site Padowetz on street Bašty No. 2, had already been settled in prehistory (Peška, Zapletalová 2006, 167-176; Procházka 2000, 30-41). It seems, however, that the key factor for the appearance of the underground granary on this site is, on the one hand, the fact that the site is located in close proximity to the socalled Zelný trh (Cabbage market) and, on the other hand, the location in the burger plot being close to the city walls. Population of the Zelný trh area was already documented in 1210 , before the city walls and street plans were completed (Procházka, Loskotová 1999, 169-188). This is also the most probable first use of the underground granary on Bašty street, because at that time the market village, together with the economic background, existed there (Dejmal, Peška 2010). The shape and depth of the underground granary from Bašty Street is comparable to the typical granaries commonly built in village environments (Kunz 2004); it is therefore supposed that the granary served a similar purpose.

\subsection{Maintenance processes of the underground granaries}

The laminated sediments excavated from the bottom of the granary infill showed high variability between the layers or bands. Generally it is possible to say that these deposits are not only the relicts of stored grains, but mainly the relicts of the insulation used for in the granary's preparation and 
Table 1. Micromorphological division and interpretation of examined sediments from the laminated bottom of the granary infill.

\begin{tabular}{cl}
\hline $\begin{array}{c}\text { Unit and } \\
\text { thickness }\end{array}$ & \multicolumn{1}{c}{ Micromorphological description } \\
\hline & $\begin{array}{l}\text { Black layer (fig. } \mathbf{4 ~ A , ~ B ) ~ t h i c k n e s ~} \mathbf{0 . 5} \mathbf{~ c m} \\
\text { Platy microstructure with common appearance of plates, and cracks. } \mathrm{C} / \mathrm{F}_{(50 \mu \mathrm{m})}=10: 90 \text {, grain size composition } \\
\text { is silty loam. Mineral fraction is composed mainly by biogenic opal }(\text { phytolites), rarely composed of } \\
\text { quartz, plagioclase and biotite. Birefringence of matrix is crystalline with black and gray colour. Black Burned redeposited straw } \\
\text { colour is provided by presence of microcharcoal accumulations. Organic matter preserved as charcoal isolation } \\
\text { and microcharcoal, partly burned non decomposed or partly decomposed organic matter. Phytoliths are } \\
\text { common, partly still with original connections. Pedofeatures observed are phosphatic infillings and coating } \\
\text { inside the charcoal fragments. }\end{array}$
\end{tabular}
inside the charcoal fragments.

$2 \quad$ Vughy to massive microstructure with occasional appearance of vughs. $\mathrm{C} / \mathrm{F}_{(50 \mu \mathrm{m})}=30: 70$, grain size composition is loam. Mineral fraction is composed of prevailing quartz, plagioclase, biotite and opaque

minerals. Birefringence of matrix is crystalline with dark brown colour. Organic matter preserved as
decomposed black dotting as well as by decomposed brown material. Pedofeatures observed are occasional

Redeposited soil FeOH staining and passage features.

\title{
Laminated darker and fragmented layer (fig. 4 D, E, F)
}

Cracky microstructure with common appearance of cracks, plates, vughs. $\mathrm{C} / \mathrm{F}_{(50 \mathrm{um})}=20: 80$, grain size composition is silty loam. Mineral fraction is composed mainly by biogenic opal (phytolites), rarely 3 composed of quartz, plagioclase and biotite. Birefringence of matrix is crystalline with orange brown colour. Organic matter preserved as decomposed black dotting, present non-decomposed or partly

$(4 \mathrm{~cm})$ decomposed dark brown organic matter. Phytoliths are common, and well preserved in their original
connections. Pedofeatures observed are fragments of phosphatic coating, strong phoshatic impregnation,
fragmented phosphate impregnation, passage features, excremental features, phosphatic circular nodules,

$(4 \mathrm{~cm})$ decomposed dark brown organic matter. Phytoliths are common, and well preserved in their original
connections. Pedofeatures observed are fragments of phosphatic coating, strong phoshatic impregnation,
fragmented phosphate impregnation, passage features, excremental features, phosphatic circular nodules,

(4 cm) decomposed dark brown organic matter. Phytoliths are common, and well preserved in their original
connections. Pedofeatures observed are fragments of phosphatic coating, strong phoshatic impregnation,
fragmented phosphate impregnation, passage features, excremental features, phosphatic circular nodules, $\mathrm{CaCO}_{3}$ circular nodules.

Redeposited straw isolation, totally impregnated by phosphate and partly fragmented

\section{Light brown unsorted layers (fig. 4 G)}

Vughy microstructure with common appearance of chambers and vughs. $\mathrm{C} / \mathrm{F}_{(50 \mu \mathrm{m})}=20: 80$, grain size 4 composition is silty loam. Mineral fraction is composed of quartz, plagioclase and biotite. Birefringence of matrix is crystalline with light brown colour. Organic matter is preserved as decomposed black dotting,

$(2.5 \mathrm{~cm}) \quad$ microcharcoal, rare non-decomposed or partly decomposed organic matter. Bones and phytoliths are present randomly distributed within matrix. Pedofeatures observed are mainly passage features and excremental features. Fragments of phosphatic coating as well as soil matrix fragments re preserved.

\section{Partly laminated fragmented dark and light hue layer (fig. 4 H, I)}

Cracky microstructure with common appearance of plates, vughs and cracks. $\mathrm{C} / \mathrm{F}_{(50 \mu \mathrm{m})}=20: 80$, grain size composition is silty loam to loam. Mineral fraction is composed by biogenic opal (phytolites) as

5 well as by quartz, plagioclase and biotite. Birefringence of matrix is crystalline with brown and light brown to gray colour which randomly appear within all the layer. Light colours appear, where the mineral fraction prevails while the darker hues point to the presence of decomposed organic matter with still visible lamination. Organic matter preserved as decomposed black dotting, present non-decomposed or partly decomposed organic matter and microcharcoal. Phytoliths are common, partly still with original connections. Pedofeatures observed are occasional present phosphatic coating, phosphatic impregnations, fragmented phosphatic features, passage features, excremental features and depleation features.

\section{Laminated, not fragmented layer (fig. $4 \mathrm{~J}$ )}

Platy microstructure with common appearance of plates, vughs and cracks. $C / F_{(50 \mu \mathrm{m})}=20: 80$, grain size composition is silty loam. Mineral fraction is composed mainly by biogenic opal (phytolites), rarely composed of quartz, plagioclase and biotite. Birefringence of matrix is crystalline with brown and gray colour. Grey colour is provided by phytolith accumulations. Organic matter preserved as decomposed
$(1.5 \mathrm{~cm}) \quad$ colour. Grey colour is provided by phytolith accumulations. Organic matter preserved as decomposed
black dotting, present non-decomposed or partly decomposed organic matter. Phytoliths are common,
partly still with original connections. Pedofeatures observed are occasional present phosphatic coating and
colour. Grey colour is provided by phytolith accumulations. Organic matter preserved as decomposed
black dotting, present non-decomposed or partly decomposed organic matter. Phytoliths are common,
partly still with original connections. Pedofeatures observed are occasional present phosphatic coating and phosphatic impregnations. Layers with darker hues (fig. $4 \mathrm{~K}, \mathrm{~L}, \mathrm{M}$ )

Vughy microstructure with common appearance of chambers and vughs. $\mathrm{C} / \mathrm{F}_{(50 \mu \mathrm{m})}=20: 80$, grain size

7 composition is silty loam. Mineral fraction is composed of quartz, plagioclase and biotite. Birefringence of matrix is crystalline with dark brown colour. Organic matter is preserved as decomposed black dotting,

microcharcoal, rare non-decomposed or partly decomposed organic matter. Phytoliths are common, partly
still in original connections or randomly distributed within matrix. Pedofeatures observed are occasional $\mathrm{FeOH}$ staining, common phosphatic coating, phosphatic impregnations, passage features and excremental features.

\author{
Redeposited loess and \\ soil from the walls of the \\ granary
}

Redeposited straw
isolation, partly

bioturbated and mixed

with the loess material
Redeposited straw isolation, only partly impregnated by phosphate
Relicts of the decomposed organic materiál originally stored inside the granary.

8 Loess background (fig. $4 \mathrm{~N}$ )

Massive microstructure with occasional appearance of horizontal pores. $\mathrm{C} / \mathrm{F}_{(50 \mu \mathrm{m})}=40: 60$, grain size

$\begin{array}{ll}\text { (More than } 30 & \begin{array}{l}\text { composition is sandy loam. Mineral fraction is composed of prevailing quartz, plagioclase, biotite and } \\ \text { opaque minerals. Birefringence of matrix is crystalline with grain brown colour. Organic matter is preserved }\end{array}\end{array}$ Human non influenced loess bacground as decomposed black dotting. Pedofeatures observed are occasional FeOH staining. 
maintenance processes. The presence of partly decomposed bunches of straw identified micromorphologically due to the presence of articulated phytoliths, was documented in different states of decomposition. At the uppermost part of the upper sample burned pieces of straw laying on an anthropogenically-induced colluvium composed of loess material and soil fragments were documented. The sealing and burning of the underground granaries is one of the maintenance processes that have been documented from historical sources (Mruškovič 1962, 56-63; Niederle 1921, 109, 237). Just burning without the use of straw was very rare (Beranová, Kubačák 2010; Kunz 2004). Burning was mainly used to harden the walls of the granary. The internal part of the granary was sealed by straw and burned for a number of days (Apáthy 1958, 352; Beranová, Lutovský 2009; Kudrnáč 1958, 242; Mruškovič 1962, 59; 1966, 82; Podolák 1965, 49). However, this is probably not the case for the granary from Bašty street, because its walls did not hold any macroscopically-identifiable signs of burning for longer periods (reddening, hardening), as well as burned soils being documented in the infill of the granary. The straw documented at the uppermost part of the bottom infill is, more or less, just $0.5 \mathrm{~mm}$ thick and similar layers are not apparent earlier. The thermal alteration of the burned straw derived from its identified mineralogical composition and the observed features in the thin sections show that the black material was not exposed to temperatures exceeding $300^{\circ} \mathrm{C}$, as well as not being exposed to a lack of oxygen in the firing process. Lack of oxygen is typical of a reducing atmosphere similar to that of the firing conditions of ceramics in pit firing, where the oxygen is very rapidly consumed by the fire. The presence of kaolinite in the mineralogical composition of the sample, as well as the presence of not fully-charred organic remnants, corresponds to firing temperatures not exceeding $400-500{ }^{\circ} \mathrm{C}$ (Maggetti 1982; Cultrone et al. 2001; Reedy 2008). Higher firing temperatures would influence the presence of calcite, as well as of illite (Maggetti 1982; Herz, Garisson 1998; Cultrone et al. 2001), and the clay matrix would have shown a fabric typical of higher temperatures (change in birefringence).

Below the "colluvial" layer, the non-burned, but heavilyimpregnated straw (by phosphates) layer documents the approximately 4-cm-thick insulation of the granary walls. This insulation had to have lasted a long time to be impregnated by decomposed cereals. A similar layer, but less impregnated, was documented below this, separated by the colluvial deposits. The sealing of the walls of these underground granaries by dry straw is probably the most common of the maintenance / storage practices that have been documented (Beranová, Lutovský 2009; Beranová, Kubačák 2010, 109; Kudrnáč 1958, 244; Kunz 2004, 99, 100; Mruškovič 1962, 63; 1966, 82; Nižňanský 1958, 269271; Podolák 1965, 49; Polla 1959, 522, 523). In this way the cereals were isolated from the walls. The straw bunches were attached to the walls by stacks or small bunches in the shape of the number one. We suppose that when the cereals were withdrawn from the granary a part of this material would just fall down and stay there. The minimally three stages of straw sealing document at least three periods of use of the granary.

The "straw-isolation" layers are separated by relatively thick (a few centimetres) layers described as a colluvium composed of loess and soil, or by loess and organic material. It is possible that this material is the result of the process of withdrawing cereal or the cleaning of the granary. On the other hand, we know from ethnographical and historical sources that the walls of the granaries were in some cases sealed not only by straw, but also coated by clay (Apáthy 1958, 352; Beranová, Lutovský 2009; Mruškovič 1962, $63 ; 1966,82)$, sometimes mixed with excrement or chaff (Beranová, Kubačák 2010, 109; Kunz 2004, 98). This might also be one of the explanations of the provenance of these "colluvial" layers, mainly of the layer marked as 5 .

\section{Conclusion}

The laminated sedimentary infill excavated from the bottom of the underground granary reflects the repeated stages of the granary's maintenance processes / preparation practices. The three bands of more or less phosphate-impregnated straw, or burned straw, are intercalated by an unsorted loess material mixed with soil fragments or decomposed organic matter. These three stages of straw sealing document a minimum of three periods of the granary's use. While the straw layers are most probably the relicts of the granary isolation through the use of dry straw, the unsorted deposits are the products of the wall erosion or the kind of sealing which was coated on the granary walls. The granary was never totally burned down. The only type of burning could not have exceeded $300{ }^{\circ} \mathrm{C}$ and was probably used only as a part of the process of granary cleaning, and not really as a way of hardening the wall.

\section{Acknowledgements}

The research was financed by the GACR project no. 17-23836S - Transformation of the Burgher House in the $13^{\text {th }}$ century (Brno-Prague-Wroclaw) - and co-financed by the internal program of the Institute of Geology ASCR in Prague No. RVO 67985831. Many thanks to David Parma for comments to the paper and to Erika Kostolnakova from Nitra who wrote her bachelor thesis on Medieval storage pits and brought to the authors many interesting ideas.

\section{References}

APÁTHY, Š. 1958: Spôsob uskladňovania hospodárskych plodín v severnom Šariši. Slovenský národopis 6/4, 347-378.

BERANOVÁ, M., KUBAČÁK, A. 2010: Dějiny zemědělstvi v Čechách a na Moravě. $1^{\text {st }}$ ed., Libri, Praha.

BERANOVÁ, M., LUTOVSKÝ, M. 2009: Slované v Čechách: Archeologie 6. - 12. století. $1^{\text {st }}$ ed., Libri, Praha.

CULTRONE, G., RODRIGUEZ-NAVARRO, C., SEBASTIAN, 
E., CAZALlA, O., DE LA TORRE, M. J. 2001: Carbonate and silicate phase reactions during ceramic firing. European Journal of Mineralogy $13,621-634$

DEJMAL, M., PEŠKA, M. 2010: Nález dvou potravinářských pecí z 12. století z ulice Bašty $2 \mathrm{v}$ Brně. The discovery of two $12^{\text {th }}$ century baking ovens in the Bašty Street in Brno. Archeologia technica 21, 113-122.

DONAT, P. 1980: Haus, Hof und Dorf in Mitteleuropa vom 7. bis 12 Jahrhundert. Schriften zur Ur- und Frühgeschichte 33, Berlin.

DOSTÁL, B. 1983: Břeclav-Pohansko III. Časně slovanské osídlení. Universita J.E. Purkyně, Brno.

GAŠPAR, A. (in press): Obilné jamy v praveku Stredného a Dolného Ponitria. Grain pits in Prehistory of Nitra region. Zborník Slovenského národného múzea 111, Archeológia 27.

HERZ, N., GARISON, E. G. 1998: Geological Methods for Archaeology. Oxford University Press, Oxford.

HOLUB, P., KOLAŘÍK, V., MERTA, D., PEŠKA, M., ZAPLETALOVÁ, D., ZUBEK, A. 2005: Ke stavu poznání nezděné měšt’anské architektury vrcholně středověkého Brna. Forum urbes medii aevi 2, 44-100.

HOLUB, P., KOLǍ̌IIK, V., MERTA, D., PEŠKA, M., SEDLAČKOVÁ, L., ZAPLETALOVÁ, D., ZUBEK, A. 2009: Přehled výzkumů za rok 2009 Brno (okr. Brno - město). Přehled výzkumu 51, 395-432.

JAN, L. 2013: Dějiny Brna 2. Středověké město. Statutární město Brno, Brno.

KLANICA, Z. 2008: Mutěnice-Zbrod. Zaniklé slovanské sídliště ze 7.-10. století. Archeologický ústav AV ČR, Brno.

KUNA, M., PROFANTOVÁ, N., BARTUŠKA, M., GOJDA, M., HAIŠMANOVÁ, L, HANYKÝŘ, V., KVĚT, R., MARYŠKA, M., MILITKÝ, J., MORAVEC, D., NOVOTNÁ, M., PEŠKE, L., PLEINER, L., SÁDLO, J., ŠREINOVÁ, B., VAŘEKA, P. 2005: Počátky raného středověku v Čechách. Archeologický ústav AV ČR, Praha.

KUDRNÁČ, J. 1970: Skladování obilí v jamách-obilnicích. In: Vznik a počátky Slovanů 2. Nakladatelství ČSAV, Praha. 233-252.

KUDRNÁČ, J., 1958: Skladování obilí v jamách - obilnicích. In: Vznik a počátky Slovanů 2. Nakladatelství ČSAV, Praha, 233-252.

KUNZ, L. 2004: Obilní jámy. Valašské muzeum v př́rodě v Rožnově pod Radhoštěm, Rožnov pod Radhoštěm.

MAGGETTI, M. 1982: Phase analysis and its significance for technology and origin. In: Olin, J. S., Franklin, A. D. 1982: Archaeological Ceramics. Smithsonian Institute Press, Washington D.C., 121-131.
MRUŠKOVIČ, Š. 1962: Príspevok k výskumu uskladňovania obilia v obilných jamách na Záhorí. Sbornik Filozofickej fakulty Univerzity Komenského-Musaica 13, 56-68.

MRUŠKOVIČ, Š. 1966: Uskladňovanie obilia v obilných jamách na juhozápadnom Slovensku. Zborník Slovenského národného múzeaEtnografia 7, 73-90.

NEKUDA, V. 2007: Středověká vesnice na Moravě. Muzejní a vlastivědná společnost, Brno.

NEKUDA, V., REICHERTOVÁ, K. 1968: Středověká keramika v Čechách a na Moravě. Moravské museum v Brně, Brno.

NIEDERLE, L., 1921: Život starých Slovanu. Základy kulturních starožitnosti slovanských. Díl III. Svazek I. Nákladem Bursíka a Kohouta. Praha.

NIŽŇANSKÝ, J. R. 1958: Brestovianske žatvy a mlatby v minulosti. Slovenský národopis 6, 238-278.

PEŠKA, M., ZAPLETALOVÁ, D. 2005: Archeologické nálezy v prostoru divadla Reduta na Zelném trhu v Brně. In: Dufková, E. (Ed.): Reduta. Divadlo na Horním náměstí. Bedřich Maleček-BM Typo, Brno, 167-176.

PLEINEROVÁ, I. 2000: Die altslawischen Dörfer von Březno bei Louny. Archeologický ústav AV ČR, Praha - Louny.

PODOLÁK, J. 1965: Pestovanie pol'nohospodárskych plodín a chov hospodárskych zvierat na Slovensku od polovice 19. do polovice 20. storočia. Agrikultúra 4, 29-77.

POLLA, B. 1959: Stredoveké obilné jamy v Budmericiach. Slovenský národopis 7, 517-557.

PROCHÁZKA, R. 2000: Zrod středověkého města na př́kladu Brna. $\mathrm{K}$ otázce odrazu společenské změny $\mathrm{v}$ archeologických pramenech. Medievalia archaeologica 2, 7-158.

PROCHÁZKA, R. 2012: Výpověd' archeologických pramenů o prostorovém vývoji jihovýchodní části Brna ve 12.-15. století na př́kladu parcely někdejšího domu Josefská 7. Archaeologia Historica 37/1, 189-208.

PROCHÁZKA, R. 2013: Parcelní zástavba vrcholně středověkého Brna a její obyvatelé I. Dominikánská 15-19, Kobližná 3. Přehled výzkumů $54 / 2,57-132$.

PROCHÁZKA, R., LOSKOTOVÁ, I. 1999: K topografii a interpretaci předlokačního osídlení brněnského historického jádra. Archeologia historica 24, 169-188.

PROCHÁZKA, R., PEŠKA, M. 2007: Základní rysy vývoje brněnské keramiky ve 12.-13/14. století. Přehled výzkumů 48, 143-299.

REEDY, C. L. 2008: Thin section petrography of Stones and Ceramic Cultural Materials. Archetype Publications, London. 
